\title{
Neural network for decision support to determine the operating mode of lined equipment
}

\author{
Vitaliy Yemelyanov ${ }^{1, *}$, Nataliya Yemelyanova $^{1}$, and Alexey Nedelkin ${ }^{2}$ \\ ${ }^{1}$ Financial University under the Government of the Russian Federation, 49 Leningradsky Prospekt, \\ Moscow, 125993, Russia \\ ${ }^{2}$ Plekhanov Russian University of Economics, 36, Stremyanny Lane, Moscow, 117997, Russia
}

\begin{abstract}
The paper presents data on the problem of determining the operational mode of lined equipment at the iron and steel works. A neural network synthesis has been performed to determine the operational mode for lined equipment. The structure of the proposed neural network for decision support is described. The results of the modelling the neural network to determine the PM350 torpedo ladle car operational mode are presented.
\end{abstract}

\section{Introduction}

In the course of industrial production, dangerous and critical production facilities and machinery are used. Lined equipment, including torpedo ladle cars, hot-metal cars and steel ladles, is considered to be critical equipment at heavy industry and machinery building facilities [1-2]. In order to prevent accidents with such type of equipment and maintain industrial safety at the production facility, a growing number of diagnostic operations and technologies to control technical condition of lined equipment are applied in production units [3-5], which, in turn, require development of new and improvement of existing technical means and information technologies.

Nowadays there are different automated systems that possess a wide range of functions to diagnose and monitor the condition of critical equipment; however, as a number of sources claim [6-8], existing systems do not provide diagnostics of the given lined equipment in the real-time mode without stopping its exploiting. It should be mentioned that modern automated systems are unable to provide complete complex (qualitative and quantitative) automated evaluation of the lining condition, which leads to a low level of objectiveness and quality of the decisions taken while exploiting the equipment. That is why, scientific research to create new systems and technologies for diagnosing lined equipment is relevant.

\footnotetext{
*Corresponding author: v.yemelyanov@gmail.com
} 


\section{Structure of neural network for decision support to determine the operation mode of lined equipment}

In the process of monitoring and technical diagnostics of the state of the lined equipment, the compulsory operation is the evaluation of the operating mode of the diagnosed equipment taking into account the revealed defects in the lining. In practice, a technologist based on his personal experience performs this operation manually. It increases subjectivity and leads to significant errors. It is proposed to automate the mode evaluation operation. The neural network usage is offered for this purpose.

The decision-making support in respect of the selection of the operating mode for lined equipment consists of three main stages.

At the first stage, a number of factors are formed and coded. On this basis, the technologist makes a decision to transfer the lined equipment to the relevant operating mode. The main factors influencing the technologist's decision on the mode of operation of lined equipment are given in Table 1 .

Table 1. Description and encoding of factors

\begin{tabular}{|c|c|l|}
\hline No & $\begin{array}{c}\text { The } \\
\text { factor } \\
\text { code }\end{array}$ & \\
\hline $\mathbf{1}$ & $\mathbf{A}$ & Performance characteristics of the lined equipment \\
\hline 1.1 & $\mathrm{a}_{\mathrm{c}}$ & The number of liquid metal castings produced or the utilization period \\
\hline 1.2 & $\mathrm{a}_{\mathrm{mc}}$ & Maximum permissible values: the number of castings or the utilization period \\
\hline 1.3 & $\mathrm{a}_{\mathrm{tm}}$ & $\begin{array}{l}\text { Maximum permissible values: the period of liquid metal in a lined equipment or } \\
\text { time of continuous operation }\end{array}$ \\
\hline 1.4 & $\mathrm{a}_{\mathrm{tr}}$ & $\begin{array}{l}\text { Actual values: the period of liquid metal in a lined equipment or time of } \\
\text { continuous operation }\end{array}$ \\
\hline $\mathbf{2}$ & $\mathbf{B}$ & Liquid metal specific features \\
\hline 2.1 & $\mathrm{~b}_{\mathrm{wn}}$ & Maximum permissible weight (mass) of the liquid metal \\
\hline 2.2 & $\mathrm{~b}_{\mathrm{wr}}$ & Actual weight (mass) of the liquid metal cast \\
\hline 2.3 & $\mathrm{~b}_{\mathrm{tm}}$ & Maximum permissible temperature of the liquid metal \\
\hline 2.4 & $\mathrm{~b}_{\mathrm{tr}}$ & Actual temperature of the liquid metal cast \\
\hline $\mathbf{3}$ & $\mathbf{C}_{\mathrm{m}}$ & Specific features of the lining for the lined equipment \\
\hline 3.1 & $\mathrm{c}_{\mathrm{pm}}$ & Maximum permissible number of the damaged sections of the lining \\
\hline 3.2 & $\mathrm{c}_{\mathrm{pr}}$ & Actual number of the damaged sections of the lining \\
\hline 3.3 & $\mathrm{c}_{\mathrm{gm}}$ & The maximum permissible depth of the lining burnout \\
\hline 3.4 & $\mathrm{c}_{\mathrm{gr}}$ & Actual depth of the lining burnout \\
\hline 3.5 & $\mathrm{c}_{\mathrm{sm}}$ & The maximum permissible area of the lining burnout \\
\hline 3.6 & $\mathrm{c}_{\mathrm{sr}}$ & Actual area of the lining burnout \\
\hline $\mathbf{4}$ & $\mathbf{D}$ & Specific features of the lined equipment housing \\
\hline 4.1 & $\mathrm{~d}_{\mathrm{H}}$ & Permissible state of the lined equipment housing \\
\hline 4.2 & $\mathrm{~d}_{\mathrm{p}}$ & Actual state of the lined equipment housing \\
\hline $\mathbf{5}$ & $\mathbf{E}$ & Features of the production process \\
\hline 5.1 & $\mathrm{e}_{\mathrm{i}}$ & The amount of planned liquid metal for transportation \\
\hline 5.2 & $\mathrm{e}_{\mathrm{f}}$ & Actual transported amount of the liquid metal \\
\hline & &
\end{tabular}

At the second stage, a criterial assessment of the state of the factors is made at the time of making a decision to transfer the lined equipment to the appropriate operating mode. The evaluation criteria for every factor and sub-factors are shown in Table 2. 
Table 2. The table of the criteria (assessment of the factor state)

\begin{tabular}{|c|c|c|c|}
\hline 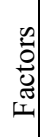 & Assessment criterion & 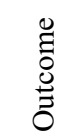 & Comments \\
\hline \multirow{6}{*}{$\mathrm{A}$} & $\left(a_{m c} \geq a_{c}\right) \wedge\left(a_{t m} \geq a_{t r}\right)$ & \multirow{2}{*}{ A1 } & Standard operation of lined equipment is permitted \\
\hline & otherwise & & Standard operation of lined equipment is prohibited \\
\hline & $\left(a_{m c}-a_{c}\right)>0$ & \multirow{2}{*}{$\mathrm{A} 2$} & $\begin{array}{l}\text { The resource of castings is not depleted or the utilization } \\
\text { period has not finished }\end{array}$ \\
\hline & $\left(a_{m c}-a_{c}\right) \leq 0$ & & $\begin{array}{l}\text { The resource of castings is depleted or the utilization period } \\
\text { finished }\end{array}$ \\
\hline & $a_{t m} \geq a_{t r}$ & \multirow{2}{*}{$\mathrm{A} 3$} & $\begin{array}{l}\text { The time of the presence of liquid metal in lined equipment } \\
\text { within the permissible limits }\end{array}$ \\
\hline & otherwise & & $\begin{array}{l}\text { Urgent discharge of liquid metal. The permissible time of } \\
\text { liquid metal in lined equipment has been exceeded }\end{array}$ \\
\hline \multirow{4}{*}{ B } & $\left(b_{w n}-b_{w r}\right)>0$ & \multirow[b]{2}{*}{ B1 } & Standard operation of lined equipment is permitted \\
\hline & otherwise & & $\begin{array}{l}\text { Standard operation of lined equipment is prohibited as the } \\
\text { weight of the metal cast exceeds the permissible value. }\end{array}$ \\
\hline & $\left(b_{t m}-b_{t r}\right)>0$ & \multirow{2}{*}{$\mathrm{B} 2$} & Standard operation of lined equipment is permitted \\
\hline & otherwise & & Standard operation of lined equipment is prohibited \\
\hline \multirow{8}{*}{$\mathrm{C}$} & $\begin{array}{l}\left(c_{\mathrm{pm}} \geq \mathrm{c}_{\mathrm{pr}}\right) \wedge\left(\mathrm{c}_{\mathrm{gm}} \geq \mathrm{c}_{\mathrm{gr}}\right) \wedge\left(\mathrm{c}_{\mathrm{s}}\right. \\
\left.\mathrm{m} \geq \mathrm{c}_{\mathrm{sr}}\right) \wedge \\
\wedge\left(\mathrm{a}_{\mathrm{mc}} \geq \mathrm{a}_{\mathrm{c}}\right) \wedge\left(\mathrm{b}_{\mathrm{tm}} \geq \mathrm{b}_{\mathrm{tr}}\right)\end{array}$ & \multirow[t]{2}{*}{$\mathrm{C} 1$} & $\begin{array}{l}\text { Standard operation of lined equipment is permitted. The } \\
\text { state of the lining equipment is satisfactory. }\end{array}$ \\
\hline & otherwise & & $\begin{array}{l}\text { Standard operation of lined equipment is prohibited. The } \\
\text { state of the lining is unsatisfactory. }\end{array}$ \\
\hline & $\begin{array}{l}\left(c_{p m}-c_{p r}\right) \wedge\left(a_{m c} \geq a_{c}\right) \\
\wedge\left(b_{t m} \geq b_{t r}\right)>0\end{array}$ & \multirow{2}{*}{$\mathrm{C} 2$} & Standard operation of lined equipment is permitted \\
\hline & otherwise & & $\begin{array}{l}\text { Standard operation of lined equipment is prohibited. There } \\
\text { is a great number of sections with the damaged lining. }\end{array}$ \\
\hline & $\begin{array}{l}\left(c_{g m}-c_{g r}\right) \wedge\left(a_{m c} \geq a_{c}\right) \\
\wedge\left(b_{t m} \geq b_{t r}\right)>0\end{array}$ & \multirow{2}{*}{$\mathrm{C} 3$} & Standard operation of lined equipment is permitted \\
\hline & otherwise & & $\begin{array}{l}\text { Standard operation of lined equipment is prohibited. The } \\
\text { depth of the lining burn-out exceeded the critical value. }\end{array}$ \\
\hline & $\begin{array}{l}\left(c_{\mathrm{gm}}-c_{\mathrm{gr}}\right) \wedge\left(\mathrm{a}_{\mathrm{mc}} \geq \mathrm{a}_{\mathrm{c}}\right) \\
\wedge\left(\mathrm{b}_{\mathrm{tm}} \geq \mathrm{b}_{\mathrm{tr}}\right)>0\end{array}$ & \multirow{2}{*}{$\mathrm{C} 4$} & Standard operation of lined equipment is permitted \\
\hline & otherwise & & $\begin{array}{l}\text { Standard operation of lined equipment is prohibited. The } \\
\text { area of the lining burn-out exceeded the critical value. }\end{array}$ \\
\hline \multirow{2}{*}{$\mathrm{D}$} & $\mathrm{d}_{\mathrm{p}} \subset \mathrm{d}_{\text {д }} \wedge\left(\mathrm{d}_{\mathrm{tm}}>\mathrm{d}_{\mathrm{tr}}\right)$ & \multirow{2}{*}{ D1 } & $\begin{array}{l}\text { The housing of the lined equipment is ready for } \\
\text { performance. }\end{array}$ \\
\hline & otherwise & & $\begin{array}{l}\text { The housing of the lined equipment is ready for } \\
\text { performance. }\end{array}$ \\
\hline \multirow{2}{*}{$\mathrm{E}$} & $\left(e_{i}-e_{f}\right) \geq 0$ & \multirow{2}{*}{ E1 } & $\begin{array}{l}\text { The plan for the liquid metal transfer has not been fulfilled. } \\
\text { Lined equipment utilization is required. }\end{array}$ \\
\hline & otherwise & & $\begin{array}{l}\text { The plan for the liquid metal transfer has not been fulfilled. } \\
\text { Lined equipment utilization is not required. }\end{array}$ \\
\hline
\end{tabular}

Every factor is characterized by an evaluation of its sub-factors. However, the set of production regulations presented in Table 2 is not sufficient to determine the mode of operation of the lined equipment, as these regulations take into account only the quantitative state of the lining, but they do not consider its qualitative state. A criterion assessment of the factors of the state of lined equipment is required to identify the possible 
outcomes in evaluating the current state. To evaluate the calculated outcomes, it is proposed to use a neural network.

At the third stage, the neural network estimation of the factors is performed, with the definition of the specific mode of operation of the lined equipment. The use of a neural network in this case is justified by the fact that it is easy to adapt this method to any lined equipment (torpedo ladle cars, steel ladle, etc.) by learning the neural network the number of outcomes and modes of operation that are characteristic for the relevant type of the lined equipment.

The structure of the neural network for determining the operation mode of lined equipment is shown in Fig. 1.

The input of the neural network receives the values of the factors. In the hidden layer of the neural network, the outcomes are evaluated based on the factors formed, taking into account the qualitative state of the lining. The output layer of the neural network consists of one neuron that performs the classification of the operating modes of lined equipment. In this case, the fragmentation of the effect of factors on the outcome is carried out in the hidden layer, i.e. input values are supplied to the input of not all the neurons of the hidden layer. Required input values are given only to those hidden layer neurons that are responsible for evaluating the relevant outcome.

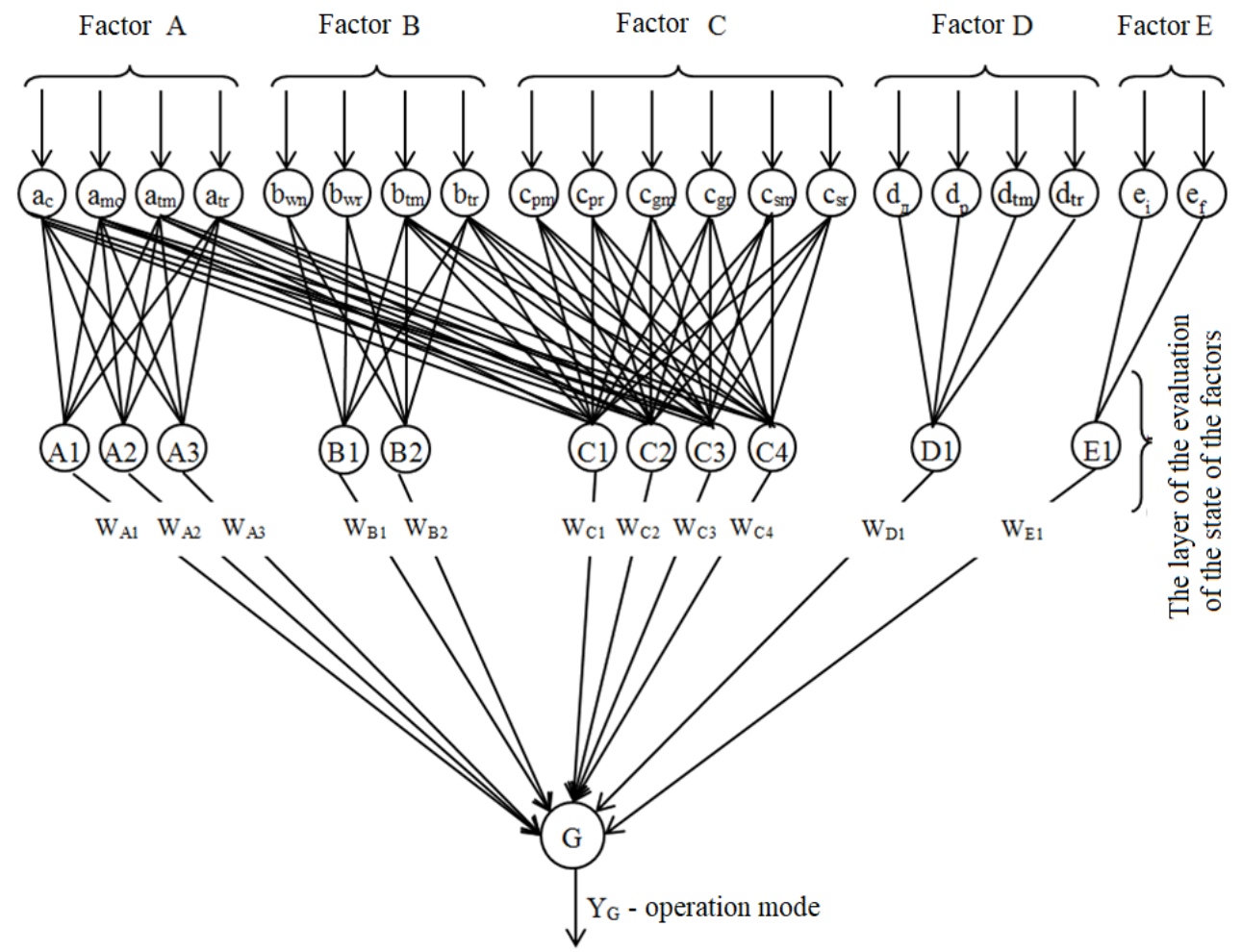

Fig. 1. The structure of the neural network for determining the operation mode for the lined equipment.

The following modes of the torpedo ladle cars are classified by means of the neural network:

1. «Normal» - the mode of the standard operation of the torpedo ladle cars;

2. «Usage + Monitoring»-the mode of operation of lined equipment with monitoring and diagnostics of its state in real time; 
3. «Inspection» - the mode of operation of the lined equipment with non-critical lining burnings, characterized by mandatory visual inspection of the lining after transportation;

4. «Diagnostic and Repair» - the mode of removal from the standard operation of the lined equipment for trouble-shooting and repair due to critical damages of the lining and housing;

5. «Not Used»-the mode of removal from the normal operation of the lined equipment due to the lack of necessity;

6. «Not Used + Repair» - a mode of removal from the standard operation due to the lack of necessity, with trouble-shooting and repair.

For the proposed structure of a neural network, the use of a sigmoid activation function is offered. The network was trained according to the back propagation algorithm [9]. The training sample comprised 620 sets of factors, compiled for the period 2014-2016 for the torpedo ladle cars of PM350 type, used at Alchevsk Iron and Steel Works. As a control and test samples, 580 sets of factors were used for every sample, affecting the possibility of using PM350 torpedo ladle cars at Alchevsk Iron and Steel Works.

To measure the quality of the classification of operating modes for torpedo ladle cars, applying a neural network, the mean square error (MSE) was assessed. In the paper, the graphs of training errors and classification of operating modes of torpedo ladle cars are constructed (Figure 2).

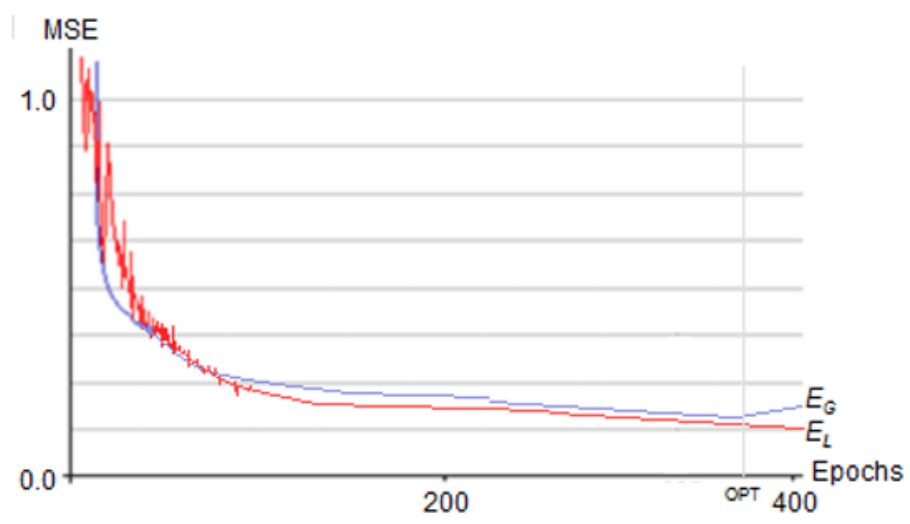

Fig. 2. Dependencies of training error $\left(E_{L}\right)$ and classification $\left(E_{G}\right)$ for a neural network

Based on these dependencies, the number of training epochs for the proposed structure of the neural network was optimally determined as 370 training epochs. The error in the classification of the operating mode of the torpedo ladle cars was 0.1301 .

The support of decision making in the process of monitoring and diagnostics of the torpedo ladle cars is the automatic determination of the operating mode applying the proposed method. Based on the method, the technologist decides what mode of operation for the torpedo ladle cars to choose. In addition, using the apparatus of neural networks, it becomes possible to train the diagnostic system implementing this method, with regard to the influence of new factors, both for new types of torpedo ladle cars (for example, MP600AC) and for other types of lined equipment (steel ladles)

\section{Conclusion}

A neural network approach was developed to support the decision-making on the choice of the operational mode for lined equipment. This approach differs from the existing neural network assessment of the factors influencing the utilization of lined equipment. It automates the operation of evaluating the operational mode of lined equipment and makes it 
possible to increase the information content of decision support processes while operating the lined equipment.

\section{References}

1. T. Fredman, J. Torrkulla and H. Saxe'n, Metallurgical And Materials Transactions 30B pp. 323-330 (1999)

2. Y. Sun, D. Zhang, M. Yang and Y. Tang, Proc. Int. Conf. on Mechanic Automation and Control Engineering (Washington, DC, USA) pp. 2589-2592 (2012)

3. L. Doukovska, V. Petkov, E. Mihailov and S. Vassileva, Cybernetics and information technologies 12(4) pp. 66-76 (2012)

4. A. Zhilenkov and S. Chernyi, Procedia Engineering 100 pp. 1247-1252 (2015)

5. A. Nyrkov, A. Zhilenkov, S. Sokolov and S. Chernyi, Automation and Remote Control 79 pp. 195-202 (2018)

6. Y. Gordon, S. Kumar, M. Freislich and Y. Yaroshenko, Steel in Translation 45(9) pp. 627-634 (2015)

7. N. Schmitt, F. Hild and E. Blond, Advances in refractories for the metallurgical industries IV pp. 39-51 (2004)

8. S. Chernyi, A. Zhilenkov, S. Sokolov and A. Nyrkov, Vibroengineering Procedia 13 pp. 261-265 (2017)

9. V.A. Yemelyanov, Naukovyi Visnyk Natsionalnoho Hirnychoho Universytetu 6 pp. 137-143 (2014) 